\title{
The Control of Annual Plans: The Experience of Tunisia
}

\section{CENTER FOR RESEARCH OII ECOIOOMIC DEVELOPMENT THE UNIVERSITY OF MICHIGAN APR 19.72}

by

J. G. KLEVE

CRED Reprints

(New Series)

No. 26

Center for Research on Economic Development

University of Michigan

Ann Arbor, Michigan 48104 


\section{Center for Research on Economic Development CRED Reprints}

No. 1. "Nigerian Government Spending on Agricultural Development: 1962/3-1966/7" by Jerome C. Wells. (The Nigerian Journal of Economic and Social Studies, November 1967)

No. 2. "Major Issues of Wage Policy in Africa" by Elliot J. Berg. (Arthur M. Ross, Editor, Industrial Relations in Economic Development, Macmillan, 1965)

No. 3. "The Myth of the Amorphous Peasantry: A Northern Nigerian Case Study" by Polly Hill (Mrs. M. E. Humphreys). (The Nigerian Journal of Economic and Social Studies, July 1968)

No. 4. "Urban Real Wages and the Nigerian Trade Union Movement, 1939-60: A Comment" by Elliot J. Berg. (Economic Development and Cultural Change, July 1969)

No. 5. "Turkish Economic Development: The First Five Year Plan, 1963-67" by Wayne W. Snyder. (The Journal of Development Studies, October 1969)

No. 6. "Hidden Trade in Hausaland" by Polly Hill, (MAN, Vol. 4, No. 3, September 1969)

No. 7. "A Comment on Peter Kilby: Industrial Relations and Wage Determination" by John F. Weeks. (The Journal of Developing Areas, Vol. 3, No. 1)

No. 8. "Measuring the Effects of Belgian Budget Policies: 1955-65" by Wayne W. Snyder. (Cahiers Economiques de Bruxelles, No. 44, 1969)

No. 9. "The Long Term Economic Development of Germany" by Wolfgang F. Stolper. Review Article of Walther G. Hoffmann, Das Wachstum der deutschen Wirtschaft, (Weltwirtschaftliches Archiv, Vol. 103, No. 2, 1969)

No. 10. "International Financial Issues in Foreign Economic Assistance to the Less Developed Countries" by Robert M. Stern. (ed. Ian G. Stewart, Economic Development and Structural Change, Edinburgh University Press, 1969, pp. 47-70)

No. 11. "Money in a Developing Economy: A Reappraisal" by Wayne W. Snyder. (The Review of Economics and Statistics, Vol. LII, No. 1, February 1970)

No. 12. "An Econometric Model of Development: Comment" by Peter Eckstein. (The American Economic Review, Vol. LX, No. 1, March 1970)

No. 13. "Who Destabilizes Primary Product Prices?" by Richard C. Porter. (Indian Economic Journal, Vol. XVI, No. 4, April-June, 1969)

No. 14. "Two Types of Planning" by Wolfgang F. Stolper. (Schweizerische Zeitschrift für Volkswirtschaft und Statistik, Vol. 106, No. 1, 1970)

No. 15. "Some Implications of Postwar Primary-Product Trends" by Richard C. Porter. (The Journal of Political Economy, Vol. 78, No. 3, May-June 1970) 
Reprinted from The Joumal of Modern African Studies, Vo1. 9, No. 2, August 1971. Copyright 1971 by Cambridge University Press. All rights reserved. 


\section{The Control of Annual Plans: the experience of Tunisia}

The year 1966 was the first for which Tunisia prepared an annual economic plan, as it has done every year since then. These plans are published, usually in April for the year concerned, the latest available at the time of writing being Rapport sur le budget économique de l'année 1970 (Tunis, 1970). Such documents are in the nature of forecasts, and experience has taught that plans are not automatically achieved. But the full report on implementation does not appear until two years later; for example, Rapport d'exécution du plan pour l'année 1968 (Tunis, 1970). Meanwhile, in order to know whether in reality things are moving as foreseen in the annual plan, monthly data have been collected since 1968 concerning a number of important economic indicators, including government capital expenditure, drawings on foreign project loans, levels of domestic production, imports, exports, and the finance received by private enterprise from banks and government subsidies.

These monthly data make it possible to compare the scheduled plans with the actual progress of economic events, and often to make more realistic forecasts for several months ahead. They provide, as it were, an early warning system that permits whatever corrective action is feasible and needed. They also clarify the interaction among different parts of the economy. Three examples will be discussed briefly here - the government capital budget, industrial output, and private investment - to show how their progress is studied in relation to changes in other sectors of the economy. Thirdly, Tunisia's level of enterprise investment can be followed on a current basis through monthly information on the financial resources actually being spent.

\section{Government investment and drawings on project loans}

The investment of the central Government is annually planned on a project-by-project basis. Some projects are entirely local; others rely on foreign participation, which may take the form of technical assistance, as for U.N. projects, or foreign loans. Normally, such loans finance only expenditure abroad, but the World Bank and some countries, such as the Federal German Republic, are willing to reimburse the Government directly for part of the local expenditure it has actually incurred. This increases the net inflow of foreign exchange. Therefore, in drawing up the annual capital budget, great care is taken to allocate the maximum sums to projects on which the local expenditure is partly reimbursable. However, it is not enough to allocate money to such projects before the year begins; it is also necessary to make sure during the year that the money is indeed spent.

Experience in Tunisia has shown that drawings on foreign project loans to the central Government are consistently overestimated in advance. Table I shows the constant revision downwards as the year proceeds.

In order to secure the reimbursement of local expenditure a number of preliminary steps have to be undertaken: (i) the work must be executed; (ii) the money must be paid by the Government; then (iii) the bill must be sent to the development bank in Western Germany, Kreditanstalt für Wiederaufbau. 
TABLE I

Drawings on German Loans to the Tunisian Government ${ }^{1}$

million Deutschmarks

\begin{tabular}{lllll}
\hline \hline & 1967 & 1968 & 1969 & 1970 \\
\hline Preliminary estimate & 3.4 & 3.5 & 5.4 & 3.2 \\
Mid-year revised estimate & 1.3 & 3.1 & 2.8 & -1.5 \\
Actual amount drawn & 1.0 & 3.0 & $1 \cdot 0$ & 1.5 \\
\hline \hline
\end{tabular}

1 These figures are taken from the statistical volume that accompanies each economic budget, the latest available being Annexe statistique au rapport sur le budget économique de l'annié 1970 (Tunis, 1970).

The rate of drawing is determined by the quantity of work done and by the bills actually paid and sent to Germany. Therefore, detailed information on progress in these preliminary steps facilitates accurate forecasts of drawings three to four months ahead. Every month a table is drawn up showing (i) the volume of work done, as measured by payment authorisations, (ii) the actual payments officially disbursed, and (iii) the total of bills sent to Germany, as recorded by the Tunisian Ministry of Foreign Affairs.

If loan drawings are going to fall short of the planned level, this may be revealed months ahead by a shortfall in payment authorisations. As soon as this is noticed, greater efforts may be made to step up progress on projects where the local expenditure is partly reimbursable.

\section{Production, exports, and imports}

For the most important products the annual plan specifies the level of output, and of imports or exports, where appropriate, including wheat, oil, phosphate rock, phosphate fertilisers, and crude oil. Consistency between production estimates on the one hand and the foreseen level of imports and/or exports is assured through a table showing the balance of resources and uses. These material balances, well known from Soviet planning, in Tunisia are drawn up for some 25 products. A simplified example, for three vertically related cotton products, is given in Table 2.

These tables are used for annual planning. The starting-points for the projection are (i) household consumption, and (ii) possible exports of the finished products: in our example, cotton cloth. The next step is to determine how much of these total uses will be produced locally and how much will be imported. When local production of the end product is determined, the consumption of the intermediate product, cotton yarn, is fixed. A forecast has then to be made of the relative amounts of cotton yarn to be imported and to be locally produced. Since local spinners depend upon imported raw cotton, the import needs of this raw material can then be predicted.

The resources/uses tables serve not only for annual planning, but also for following the execution of the plan. Through such a formulation it becomes possible to find out why actual exports or imports are different from what has been planned. Suppose, for example, that imports of raw cotton are running 
TABLB 2

Resources and Uses, Cotton Products, Tunisia, 1967

metric tonse

\begin{tabular}{|c|c|c|c|c|c|}
\hline & $\begin{array}{l}\text { Cotton } \\
\text { cloth }\end{array}$ & $\begin{array}{l}\text { Technical } \\
\text { relation }\end{array}$ & $\begin{array}{l}\text { Cotton } \\
\text { yarn }\end{array}$ & $\begin{array}{l}\text { Technical } \\
\text { relation }\end{array}$ & $\underset{\text { cotton }}{\operatorname{Rat}}$ \\
\hline \multicolumn{6}{|l|}{ Resources } \\
\hline Production & $7,130 \leftarrow$ & \multirow{7}{*}{$\begin{array}{l}\text { For I ton } \\
\text { cloth: } \\
\text { I.06 ton } \\
\text { yarn }\end{array}$} & $3,850 \leftarrow$ & \multirow{7}{*}{$\begin{array}{l}\text { For I ton } \\
\text { yarn: } \\
1 \cdot 1 \text { ton } \\
\text { raw cotton }\end{array}$} & - \\
\hline $\begin{array}{l}\text { Imports } \\
\text { Stock decrease }\end{array}$ & $\begin{array}{r}1,266 \\
800\end{array}$ & & 3,440 & & 4,345 \\
\hline Total & 9,196 & & 7,500 & & 4,345 \\
\hline Uses & & & & & \\
\hline $\begin{array}{l}\text { Local consumption } \\
\text { Exports }\end{array}$ & $\begin{array}{r}8,519 \\
677\end{array}$ & & $-7,500$ & & $-4,215$ \\
\hline Stock increase & - & & - & & 130 \\
\hline Total & 9,196 & & 7,500 & & 4,345 \\
\hline
\end{tabular}

at a lower level than foreseen. A table of uses and resources for the part of the year that has already passed may then clarify whether the lower imports can be explained by a drawing on domestic stocks, or whether a diminishing output of cotton yarn has reduced the demand for imported raw materials. In the first case, one may expect higher than normal imports during the rest of the year. On the other hand, if reduced imports of raw cotton are due to a low level of cotton yarn production, smaller imports of raw cotton become a datum and the import component in the balance of payments will have to be revised.

The balance of payments is only one aspect of the process of analysis and revision. The question will also have to be answered why cotton yarn production is below expected levels. This question necessitates another table of resources and uses. It might be due to competition from imported yarn, or to a smaller demand for yarn if the production of the weaving mills is falling off.

To take another example, exports of raw phosphate rock may be below the projected level. This might be the result of higher domestic use for fertiliser production. This would constitute a welcome development and lower exports of phosphate rock will be made good by higher earnings from fertilisers. If the lower exports are caused by a production shortfall, little can be done about it in the short term, and the plan forecast of exports and production should be revised. Or, if exports are relatively low while stocks are building up, marketing difficulties are the root of the trouble and a short-term solution has to be found to reduce stocks.

In Tunisia's small and developing economy it is in this manner possible to keep track of the main developments in the field of production, of exports and (to a much smaller extent) of imports by following a relatively small number of products. The analysis is not difficult and the only practical problem is simply that somebody has to do it on a regular basis for these key products: 
that is to get the basic information, to put it into a resources/uses table for each complete period, and to analyse or extrapolate the results for the whole of the year.

\section{Financing private investment}

The list of projects to be undertaken by private enterprise is an essential element, especially in an annual plan, for which detailed information and preparation of projects must be well advanced. In the case of Tunisia the development budget not only lists the projects but also specifies how the firms are going to finance their future capital outlay. Checking the realisation of their investment plans is just as important as including their list of projects in the annual plan itself.

There can be no question of assessing on a monthly basis the value of the physical work done. The contractors themselves would find it difficult to measure the monthly progress on a factory site. The aim is rather to revise annually the level of private investment activities, with monthly revision for those projects for which new information has become available.

In Tunisia we have found that progress in the realisation of projects can best be analysed by a regular review of the finance available to firms. Not all the different sources of finance can be studied regularly. Thus, it is not easily possible for a planning bureau to know during the year what amounts are available in the form of profits, depreciation allowances, local suppliers' credits, or share capital (both local and foreign). But on the other hand it is possible in Tunisia to collect monthly information on the foreign credits, local bank credits, and government subsidies made available to firms.

The equipment component in all major projects of firms is financed by external sources. When these are of public origin, drawings are brought to the attention of the Ministry of Foreign Affairs, and this information makes it possible to study the current execution of the projects. External resources may also consist of private supplier credits. The annual plan specifies the projects for which the Ministry of Finance has authorised firms to buy equipment in this way. Ministry control of this costly form of credit was instituted in 1966. The actual authorisations of foreign supplier credits make it possible to know which projects are being implemented.

In Tunisia medium- and long-term bank credits seldom come from the banks' own resources; but they have set up special funds for this purpose, financed by government subsidies or by foreign loans. In both cases the planning bureau can secure detailed information about lending operations. The most important special fund sponsored by the Government is the one that finances private agricultural development. In this sector, savings supply only a small portion of investment, so capital outlays can be revealed by the operations of the special fund. The Industrial Development Bank (Société nationale d'investissements) has set up a special fund financed by an external loan from the International Finance Corporation. Statements issued at regular intervals, showing contracted credits and disbursements for each enterprise, indicate which projects are going ahead.

Other projects depend for their execution on direct government subsidies. It goes without saying that the planning organisation is well placed to know 
how much of the authorised capital subsidies have actually been disbursed, and thus how far these projects are being executed.

It is true that all this information is available because Tunisia is a country where the Government relies on many direct controls. The fact that they exist does not, however, automatically imply that these controls are exercised in a way that is consistent with the plan. But the planning bureau should use them to secure information about the finance actually at the disposal of firms. Through such knowledge lengthy and bothersome official questionnaires are avoided and attention is concentrated on the points of divergence between the plan and the actual process of development.

J. G. KLEVE

Tunis 


\section{CRED Reprint Series}

No. 16. "Measuring the Effects of German Budget Policies, 1955-65" by Wayne W. Snyder. (Weltwirtschaftliches Archiv, Vol. 104, No. 2 , 1970)

No. 17. "Politics, Privilege and Progress in Liberia - A Review Article" by Elliot J. Berg. (Liberian Studies Journal, Vol. II, No. 2, 1970)

No. 18. "Terminal-Year Investment in Finite-Horizon Planning Models" by Richard C. Porter. (Pakistan Development Review, Summer, 1970)

No. 19. "Measuring the Stabilizing Effects of Social Security Programs in 7 Countries, 1955-65" by Wayne W. Snyder. (National Tax Journal, September, 1970)

No. 20. "Measuring Economic Stabilization: 1955-65" by Wayne W. Snyder. (The American Economic Review, December, 1970)

No. 21. "Further Comment on the Kilby/Weeks Debate: An Empirical Rejoinder" by John F. Weeks. (The Journal of Developing Areas, January, 1971)

No. 22. "Structural Transformation versus Gradualism: Recent Economic Development in Ghana and the Ivory Coast" by Elliot J. Berg. (Ghana and the Ivory Coast: Perspectives on Modernization, edited by Philip Foster and Aristide R. Zolberg. Published by University of Chicago Press, 1971, pp. 187-230)

No. 23. "Budget, Economic Policy, and Economic Performance in Underdeveloped Countries" by Wolfgang F. Stolper. (Kieler Vorträge, Neue Folge 69, 1971, 33 pp.)

No. 24. "Limitations of Comprehensive Planning in the Face of Comprehensive Uncertainty: Crisis of Planning or Crisis of Planners?" by Wolfgang F. Stolper. (Weltwirtschaftliches Archiv, Vol. 107, No. 1, 1971, pp. 1-32).

No. 25. "Managing Money and Credit in a Developing Economy" by Wayne W. Snyder. (Malayan Economic Review, Vol. XVI, No. 1, April 1971, pp. 1-12)

No. 26. "The Control of Annual Plans: The Experience of Tunisia" by J. G. Kleve. (Journal of Modern African Studies, Cambridge University Press, Vol. 9, No. 2, August 1971, pp. 306-310) 
